\title{
POTENSI SUMBER DAYA ALAM FOSIL KAYU DI DAERAH GORONTALO
}

\section{Natural Wood Fossil Resources Potential in Gorontalo}

\author{
Sunarty Suly Eraku ${ }^{\mathrm{a}}$, Aang Panji Permana ${ }^{\mathrm{b}}$, Evi Hulukati ${ }^{\mathrm{c}}$ \\ ${ }^{a}$ Prodi Pendidikan Geografi Universitas Negeri Gorontalo, Jalan Jenderal Sudirman No 6 Kota Gorontalo, 96128 \\ ${ }^{b}$ Prodi Teknik Geologi Universitas Negeri Gorontalo, Jalan Jenderal Sudirman No 6 Kota Gorontalo, 96128 - \\ aang@ung.ac.id \\ ${ }^{c}$ Prodi Pendidikan Matematika Universitas Negeri Gorontalo, Jalan Jenderal Sudirman No 6 Kota Gorontalo, \\ 96128
}

\begin{abstract}
Gorontalo area is part of the arc volcano - plutonic North Sulawesi predominantly volcanic rocks and intrusif rock Eocene to Quaternary. The tectonic position makes the Gorontalo area of natural resource mining prospects both metallic and non metallic minerals. One of them is a non-metal potential of petrified wood. The purpose of this study to analyze the condition of geomorphology, lithology, stratgraphy, and determine the nature of the physical characteristics of petrified wood in order to formulate feasibility as gemstones. The method used qualitative and quantitative results of the field survey which is then compiled the results of the laboratory. Field analysis in the form of geological mapping, sampling and documentation of geological data. The laboratory analysis conducted mineralogical and geochemistry analysis in the form of X-Ray Diffraction (XRD) and X-Ray Fluorescence (XRF). Dissemination of research results, the petrified wood in Tohupo River and Molannihu River. Petrified wood found in fluvial and alluvial sediment in tuffaceous sandstone layer with two types of insitu and transported. Results of laboratory analysis both mineralogy and gochemistry indicates that the mineral constituent of petrified wood are Quartz ( $\left.\mathrm{SiO}_{2}\right)$ with good quality so worty as a gemstone because of its aesthetic, translucent and hardness 7 Mohs Scale.
\end{abstract}

Keywords: Gorontalo District, Petrified Wood, Gemstone

(Diterima: 03-02-2017; Disetujui: 28-03-2017)

\section{Pendahuluan}

Fosil ialah sisa tulang belulang binatang atau sisasisa tumbuhan dari zaman purba yang membatu atau yang tertanam di bawah lapisan tanah (Badudu dan Zein, 2001). Suatu benda bisa disebut fosil apabila memiliki syarat antara lain: merupakan sisa organisme, terawetkan secara alamiah, pada umumnya padat/kompak/keras, mengandung kadar oksigen dalam jumlah sedikit, dan berumur lebih dari 10.000 tahun (Palmer, 2002). Fosil kayu merupakan kayu yang sudah membatu dimana semua bahan oganiknya telah digantikan oleh mineral (silika dan sjenis kuarsa), dengan struktur kayu tetap terjaga. Proses pembentukan fosil kayu dimulai dari masuknya air yang mengandung mineral ke dalam sel-sel kayu melapisi lignin dan selulosa yang membusuk sehingga menjadi batu. Proses terbentuknya fosil kayu mirip dengan terbentuknya fosil materi lain, yaitu karena permineralisasi secara kimiawi dan fisika melalui proses yang sangat panjang (Andianto et al., 2012).

Fosil kayu memiliki nilai sejarah yang tak ternilai karena dapat menjadi bukti hidupnya suatu jenis pohon tertentu pada zaman pra sejarah. Salah satu ciri ditemukannya fosil kayu adalah ditemukannya produk gunung api tersier. Menurut Dewi (2013), fosil kayu yang ditemukan di Indonesia berasal dari masa miocene sampai pliocene yaitu 25 juta tahun BP (Before Present) sampai 2 juta tahun BP.
Daerah Gorontalo merupakan bagian dari lajur Vukano-Plutonik Sulawesi Utara yang didominasi batuan gunungapi dan batuan terobosan yang berumur Eosen hingga Kuarter (Sompotan, 2012). Posisi tekonik tersbut menjadikan daerah Gorontalo kaya sumber daya alam tambang baik mineral logam maupun non logam (bahan galian). Sumber daya alam tersebut akan dirasakan jika kegiatan eksplorasi geologi yang dilakukan benar-benar terencana dan terukur dengan baik. Jenis sumber daya alam yang ada di daerah Gorontalo meliputi emas, tembaga, batugamping, granit, feldspar, andesit dan fosil kayu (petrified wood) (sebutkan sumbernya). Namun sayangnya untuk pemanfaatan fosil kayu yang ada di daerah Gorontalo masih kurang. Untuk pemanfaatan fosil kayu sampai saat ini masih belum maksimal, karena kurangnya atau belum adanya informasi analisa geologi terhadap potensi fosil kayu yang ada di Gorontalo.

Daerah penelitian merupakan bagian dari lengan utara Sulawesi. Sebagian besar daerah ini ditempati oleh batuan gunung api tersier. Di wilayah tengah bagian timur daerah penelitian dijumpai dataran rendah yang berbentuk memanjang, terbentang dari Danau Limboto ke Lembah Paguyaman yang diduga semula merupakan danau (Gambar 1). Pola aliran sungai di wilayah ini umumnya adalah subdenritik dan subparalel (Bachri et al., 1994). Stratigrafi regional daerah penelitian mengacu pada peta geologi Lembar 
Tilamuta dari Pusat Penelitian dan Pengembangan Geologi, stratigrafi wilayah daerah penelitian disusun oleh formasi Batugamping Terumbu (Q1), Batuan
Gunungapi Pinogu (TQpv) dan Diorit Boliohuto (Tmbo) (Trail et al., 1974).

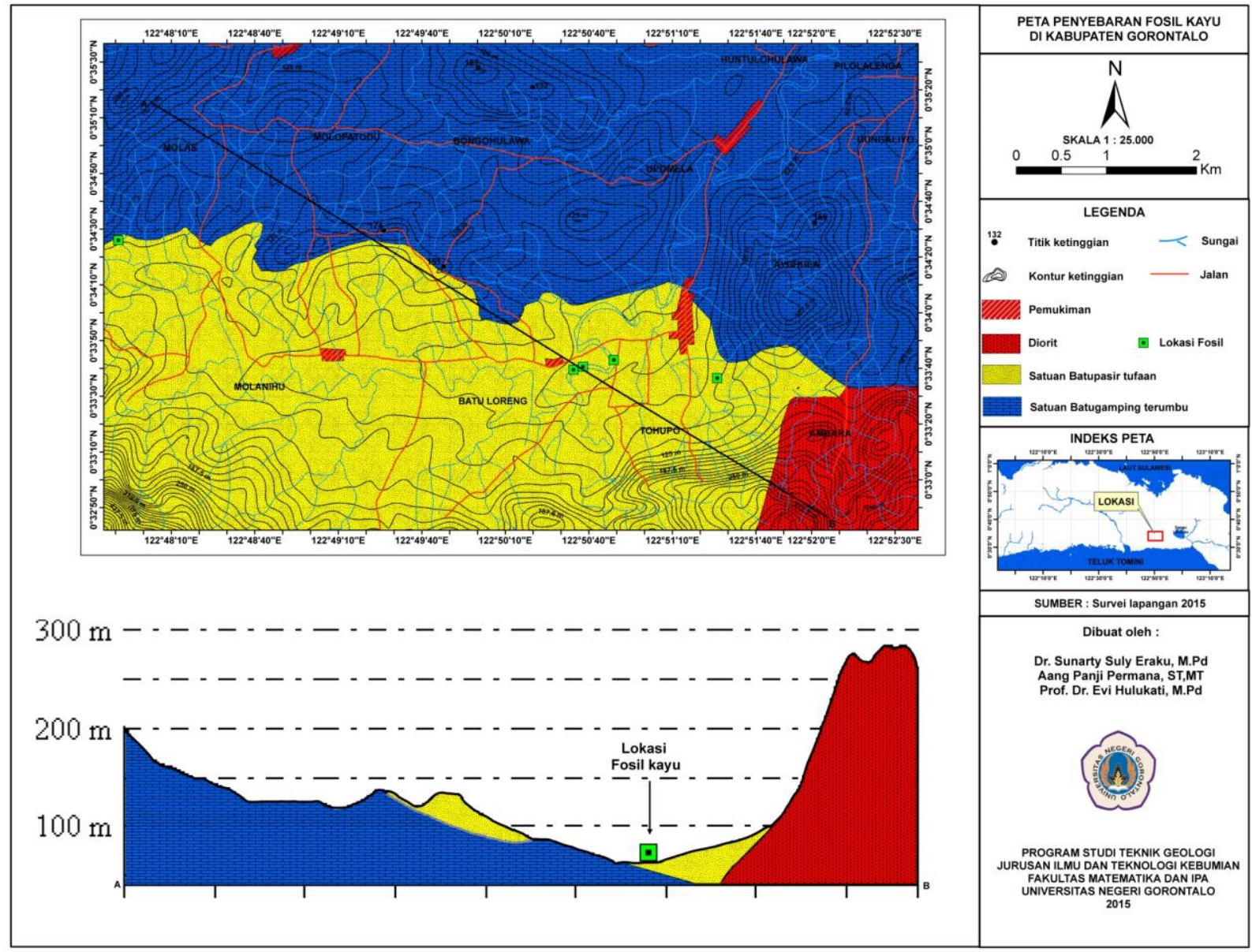

Gambar 1. Lokasi penelitian fosil kayu yang ada di daerah Gorontalo

Pada awalnya Lengan Utara Sulawesi ini merupakan bagian dari Lengan Selatan Sulawesi yang memanjang utara-selatan. Namun pada waktu tumbukan antara Busur Gunungapi Sulawesi Barat dan mikrokontinen atau kepingan benua pada Neogen, Lengan Utara terputar searah jarum jam (Hamilton, 1979; Kavelieris et al., 1992). Daerah penelitian didominasi yang merupakan Lengan Utara Sulawesi terdiri atas sesar naik, sesar mendatar, sesar turun dan kawah gunung api. Struktur utama di Lengan Utara Sulawesi adalah sesar Gorontalo yang merupakan sesar mendatar menganan. Sesar ini memotong Lengan Utara Sulawesi dan berarah barat lauttenggara. Katili (1970) menyebutkan sesar ini dicirikan oleh kelurusan sungai, sepanjang kelurusan terdapat tambang emas dan mata air panas. Berdasarkan bentuk pantai Selat Gorontalo dan Selat Paleleh, sesar ini merupakan sesar mendatar mengiri. Berdasarkan konsep escape tectonics, setelah tumbukan kepingan benua dengan Sulawesi Barat muncul gaya berarah timur-timur laut sehingga Sesar Gorontalo merupakan sesar mendatar menganan (Satyana, 2007). Namun kenampakan lapangan menunjukkan adanya pergeseran ke arah kiri (sinistral fault) batuan gunung api berlapis yang diduga berumur
Plio-Plistosen sehingga Sesar Gorontalo diduga merupakan sesar mendatar ke arah kiri (sinistral fault). Molnar dan Dayem (2010) mengemukakan bahwa sesar Gorontalo merupakan sesar mendatar ke arah kiri (sinistral fault) yang masih aktif dengan kecepatan pergeseran $11 \mathrm{~mm} /$ tahun.

Penelitian ini dilakukan untuk memetakan potensi fosil kayu sebagai sumber daya alam mineral batu mulia di Kabupaten Gorontalo. Hasil penelitian ini dapat dapat digunakan sebagai kajian pengembangan sumber daya alam lainnya. Pemetaan potensi fosil kayu ini perlu dilakukan karena selama ini masyarakat Gorontalo belum tahu karakteristik sumberdaya alam mineral berupa fosil kayu berdasarkan kondisi fisik, kekerasan, warna, bentuk dan kekhasan lainnya termasuk mineral pengisi atau penyusun fosil kayu tersebut. Masyarakat masih menganggap nilai jual fosil kayu belum tinggi padahal ciri khas fosil kayu tersebut memiliki nilai estetika yang langka dibanding mineral atau batu lainnya yang sering disebut sebagai batu mulia (gemstone). Dari sisi ekonomi pengembangan eksplorasi fosil kayu ini diharapkan dapat meningkatkan kesejahteraan ekonomi masyarakat dan pendapatan asli daerah (PAD). 
Penelitian akan dilakukan di daerah Bongomeme dan Tabongo Kabupaten Gorontalo Provinsi Gorontalo yang berdasarkan hasil identifikasi awal mempunyai potensi sumber daya fosil kayu. Hasil identifikasi awal (peneliti...) tersebut harus ditingkatan dalam riset yang lebih detail. Untuk itu survei lapangan dilakukan secara maksimal mulai dari geomorfologi, litologi, stratigrafi dan struktur geologi. Data hasil survei lapangan yang diperoleh nantinya masih butuh lagi dilakukan analisa sampel fosil kayu di laboratorium. Berdasarkan pemaparan di atas daerah Bongomeme dan Batudaa menarik untuk diteliti untuk dianalisa geologi terhadap potensi fosil kayu sebagai sumber daya mineral batu mulia.

Dilatarbelakangi pernyataan tersebut diatas, maka permasalahan yang diangkat bagaimana penyebaran fosil kayu di daerah penelitian dan karakteristik fosil kayu sebagai batu mulia. Guna memecahkan masalah tersebut maka tujuan penelitian ini adalah :

1. Menganalisis kondisi geomorfologi lokasi penelitian.

2. Mengkaji litologi dan stratigrafi di daerah penelitian.

3. Menentukan kualitas fosil kayu berdasarkan sifat fisik, dan karakteristik yang ada di daerah penelitian.

4. Merumuskan kelayakan fosil kayu daerah penelitian sebagai batu mulia unggulan .

\section{Metode}

Metode pendekatan penelitian secara garis besar akan menghasilkan kualitas dan pola penyebaran fosil kayu di daerah Gorontalo. Berdasarkan kualitas tersebut ditentukan kelayakan secara geologi sebagai batu mulia unggulan. Tahapan penelitian diawali survei lapangan yang meliputi pemetaan geologi, pengambilan sampel (sampling) dan dokumentasi data geologi. Pemetaan geologi merupakan pemetaan dengan mengambil data batuan (litologi), morfologi permukaan bumi (geomorfologi), struktur geologi dan urutan batuan terbentuk (stratigrafi). Sedangkan pengambilan sampel dilakukan melalui pengambil batuan dan fosil kayu yang masih segar (fresh) atau belum lapuk. Dan untuk dokumentasi data geologi meliputi koordinat pengambilan sampel, foto lokasi dan sampel.

Tahapan berikutnya setelah survei lapangan adalah analisa mineralogi, analisa geokimia XRD dan XRF. Untuk analisa mineralogi meliputi analisa sampel fosil kayu dan batuan sekitarnya secara langsung dengan pengamatan mata biasa tanpa bantuan mikroskop. Data yang diperoleh dari analisa mineralogi terdiri dari warna, cerat, sifat mineral terhadap sinar, tingkat kekerasan (hardness), belahan, sifat kemagnetan dan daya hantar listrik. Untuk analisa sifat mineral terhadap sinar dengan menggunakan lampu penerangan yang diberikan pada satu sisi sampel hingga menebus sisi yang satunya dengan dilihat tingkat tembus sinarnya. Analisa tingkat kekerasan menggunakan alat khusus yakni hardness tester yang diukur ketahanan sampel menerima goresan dari hardness tester. Analisa sifat kemagnetan menggunakan magnet melihat kemampuan daya tarik kemagnetan sampel dan hal sama untuk daya hantar listrik dilihat apakah mampu menghantarkan listrik.

Untuk analisa geokimia XRD dan XRF dilakukan di laboratorium Geokimia Fakultas MIPA Universitas Negeri Gorontalo. XRD, teknik analisa untuk struktur suatu mineral yang terkandung dalam suatu bahan tambang dan assosiasinya. XRD memberikan informasi mengenai bentuk molekul dan berapa sudut kristalnya. XRD bekerja berdasarkan difraksi sinar X yang dihamburkan oleh sudut kristal material yang dianalisa. Sedangkan XRF, mirip dengan XRD namun perbedaannya adalah fluoresensinya yang digunakan untuk analisa. Suatu material tambang, cukup dibuat homogen dengan digerus dan dipadatkan atau dilebur, dicetak menjadi semacam bead atau koin, tentunya dengan penimbangan tertentu. XRF lebih akurat dibandingkan XRD secara kuantitatif. XRF bisa memberikan data baik dalam bentuk elemen maupun oksida. Analisanya pun relatif cepat karena simultan (beberapa elemen atau oksida bisa dianalisa sekaligus dalam sekali running).

Kemudian data dari survei lapangan dan analisa laboratorium dikomprehensifkan untuk menentukan kualitas dan penyebaran fosil kayu sebagai batu mulia. Setelah diketahui kualitasnya dan penyebarannya terkait besarnya potensi maka dilakukan perumusan kelayakan geologi terhadap fosil kayu sebagai batu mulia unggulan (Gambar 2).

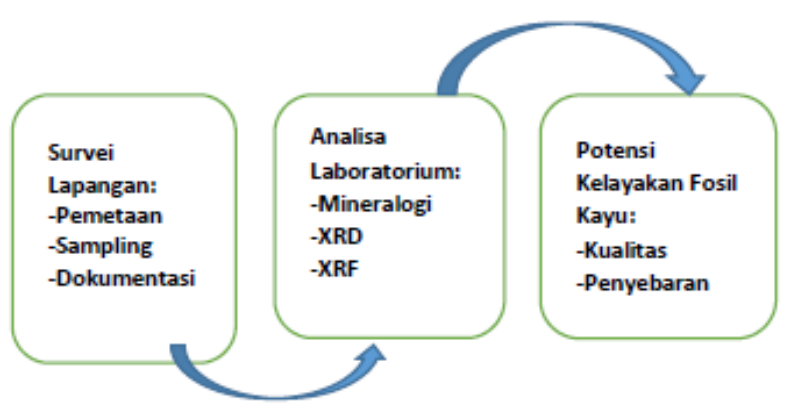

Gambar 2. Diagram alur penelitian

\section{Hasil dan Pembahasan}

Geomorfologi lokasi penelitian berada di bagian selatan lengan utara Sulawesi tepatnya dari sisi selatan danau Limboto terdiri dari satuan morfologi pegunungan dan dataran. Satuan morfologi pengunungan patahan, satuan dataran fluvial dan satuan dataran alluvial. Untuk lokasi penyebaran fosil kayu terdapat pada satuan dataran alluvial dan satuan dataran fluvial di sepanjang sungai utama. Stadia sungai utama dewasa dicirikan bentuk lembah yang sudah U, endapan point bar, channel bar dan sudah bermeander. Arah aliran sungai dari hulu ke hilir bermeander. 
Geologi daerah penelitian terdiri dari batu lempung, tuf, batu pasir tufaan dan konglomerat. Diantara batuan terdapat dinding sungai yang memiliki ketebalan sekitar 10 meter dengan dimensi panjang singkapan lebih dari 100 meter. Selain itu terdapat singkapan endapan fluvial dan endapan alluvial. Berdasarkan analisa stratigrafi maka batu lempung diendapkan lebih awal berumur lebih tua kemudian diatasnya diendapan selaras batu pasir tufaan mengandung fosil kayu kemudian diatasnya terendapkan konglomerat (Gambar 3).

Penyebaran fosil kayu di daerah penelitian secara genesa ada yang insitu (terbentuk pada tempatnya fosil kayu diendapkan) dan transported (fosil kayu yang terbentuk sudah mengalami transport atau perubahan tempat akibat terangkut oleh air sungai). Penyebaran singkapan fosil kayu jenis insitu terdapat di dua kecamatan yakni Bongomeme dan Tabongo. Untuk Kecamatan Bongomeme penyebaran di Desa Tohupo dan Desa Upomela sedangkan penyebaran di Kecamatan Tabongo ada di Desa Limehe. Singkapan fosil kayu jenis insitu terdapat di dua aliran sungai yakni Sungai Tohupo dan Sungai Molannihu serta di perkebunan kelapa.

Singkapan fosil kayu jenis insitu yang sangat signifikan terdapat pada tebing Sungai Tohupo. Dimensi tinggi tebing sekitar 10 meter dengan panjang mencapai 100 meter pada koordinat geografis 00'33'39,5" Lintang Utara dan 122'50'34,5" Bujur Timur (Gambar 4). Untuk singkapan fosil kayu jenis insitu di Sungai Molannihu juga terdapat di tebing sungai pada koordinat geografis $00^{\circ} 34^{\prime} 26^{\prime \prime}$ Lintang Utara dan $122^{\circ} 47^{\prime} 51^{\prime \prime}$ Bujur Timur. Selain itu, fosil kayu jenis insitu ada yang tersingkap pada endapan alluvial yang sudah dimanfaatkan menjadi perkebunan kelapa pada posisi koordinat geografis $00^{\circ} 33$ ' $36,2^{\prime}$ " Lintang Utara dan $122^{\circ} 51^{\prime}$ 26,1" Bujur Timur.

Penyebaran fosil kayu jenis transported terdapat di lembah aliran Sungai Tohupo dan Sungai Desa Limehe. Posisi penyebaran fosil kayu di Sungai Tohupo pada koordinat geografis $00^{\circ} 33^{\prime} 46,6^{\prime \prime}$ LU dan $122^{\circ} 50$ '47,3" BT sepanjang $1 \mathrm{~km}$. Sedangkan di Sungai Desa Limehe penyebarannya sepanjang 20 meter pada koordinat 00³'40,6" LU dan $122^{\circ} 50$ '37,9” BT (Gambar 5).

Perbedaan antara fosil kayu yang insitu dan transported yang paling mudah dikenali yakni melihat dimensi ukuran fosil kayunya. Ukuran fosil kayu yang insitu lebih besar dari fosil kayu jenis transported. Untuk fosil kayu jenis insitu bisa mencapai panjang 20 meter atau satu ukuran batang pohon besar yang masih utuh sedangkan fosil kayu jenis transported dimensinya hanya 1 meteran.

Sementara itu analisa yang dilakukan pertama kali di laboratorium adalah analisa mineralogi. Analisa ini dilakukan untuk mengetahui sifat fisik mineral yang akan diuji mulai dari warna mineral, cerat mineral, sifat mineral terhadap sinar, tingkat kekerasan (hardness), belahan, sifat kemagnetan dan daya hantar listrik. Tujuan mengetahui sifat fisik mineral dan karakteristik serta mengenal jenis mineral penyusun fosil kayu dan kualitas jenis kayunya. Hasil analisa mineralogi mineral penyusun fosil kayu dapat dilihat pada Tabel 1. Berdasarkan hasil analisa mineralogi terhadap sifat fisik mineral penyusun fosil kayu maka dapat disimpulkan adalah mineral Quartz (Kuarsa) dengan rumus kimia $\mathrm{SiO}_{2}$.

Selain analisa mineralogi, juga dilakukan analisa geokimia secara detail. Tujuannya agar hasil penelitian pemetaan fosil kayu yang dihasilkan sangat lengkap dan akurat sehingga akan menjadi sumber referensi yang dapat dipertanggungjawabkan. Untuk itu dilakukan analisa XRD dan XRF. Untuk analisa XRD menunjukan hasil bahwa sampel fosil kayu disusun oleh $100 \%$ mineral Quartz (Kuarsa) dengan rumus kimia $\mathrm{SiO}_{2}$ (Gambar 6).

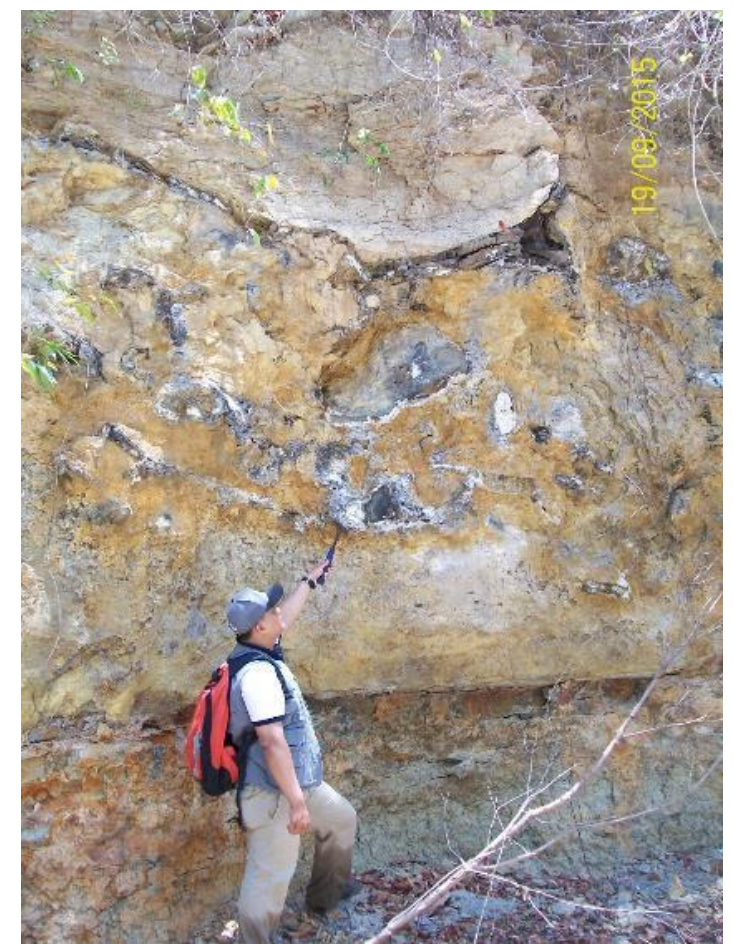

Gambar 3. Singkapan fosil kayu yang terdapat pada batupasir tufaan

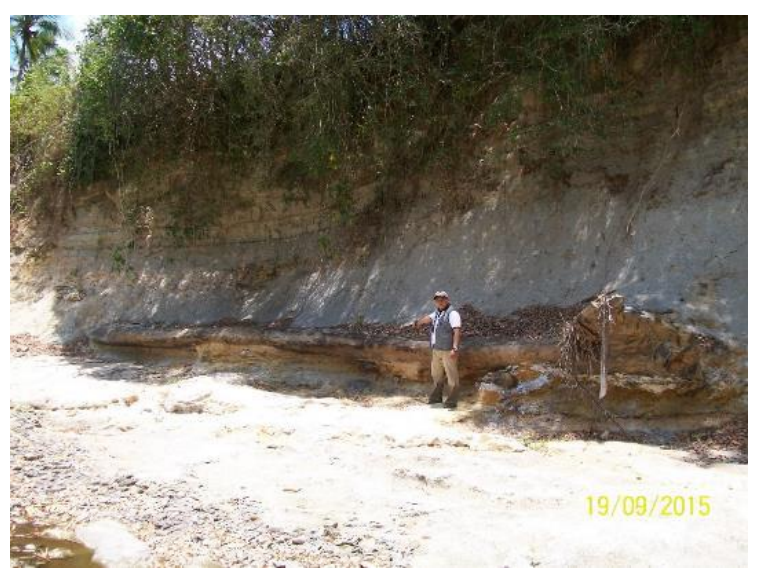

Gambar 4. Singkapan fosil kayu insitu yang panjangnya mencapai sekitar 20 meter di dinding sungai 


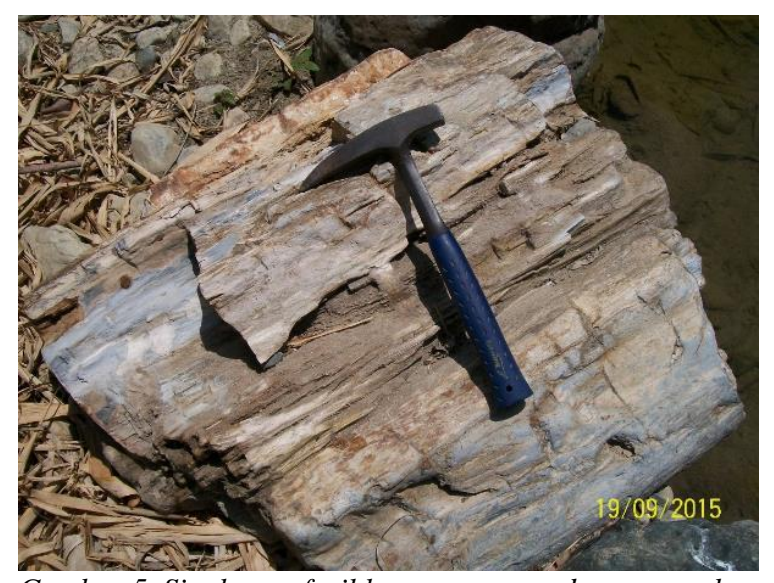

Gambar 5. Singkapan fosil kayu transported yang tersebar di sepanjang sungai

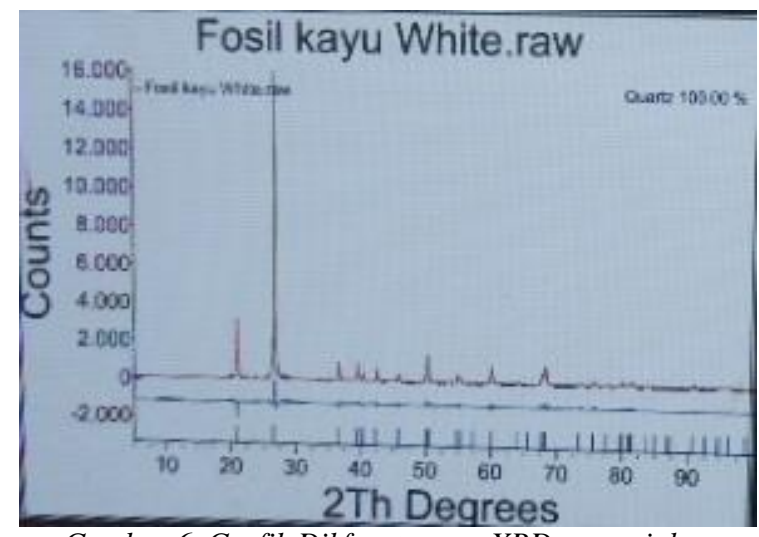

Gambar 6. Grafik Dikfragtogram XRD menunjukan mineral penyusun fosil kayu 100\% Quartz (Kuarsa)

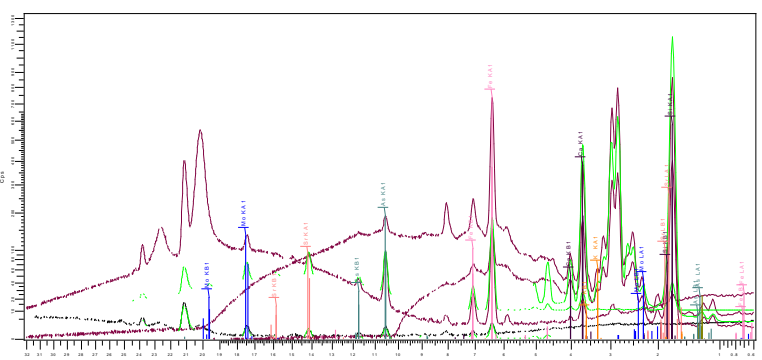

Gambar 7. Hasil analisa XRF yang menunjukan senyawa penyusun fosil kayu senyawa terdiri $\mathrm{SiO} 2$ 90,84\%, $\mathrm{Fe} 2 \mathrm{O} 3$ $3,95 \%, \mathrm{CaO} 2,03 \%$ dan senyawa lainnya

Sementara itu untuk analisa XRF yang dilakukan pada beberapa sampel fosil kayu menunjukan hasil yang mendukung data mineralogi dan XRD. Dengan perincian lebih lengkap mengenai senyawa atau unsur penyusunnya terdiri dari senyawa $\mathrm{SiO}_{2} 90,84 \%, \mathrm{Fe}_{2} \mathrm{O}_{3}$ $3,95 \%, \mathrm{CaO} 2,03 \%$ dan beberapa senyawa lainnya (Gambar 7).

Analisa dari data lapangan dan laboratorium baik analisa mineralogi maupun analisa XRD dan XRF menunjukan bahwa mineral penyusun utama fosil kayu yang ada di Kabupaten Gorontalo adalah mineral Quartz (Kuarsa) dengan senyawa $\mathrm{SiO}_{2}$ yang persentasenya 90-100\%. Mengacu hasil analisa mineralogi dan geokimia yang dilakukan pada sampel fosil kayu menunjukan bahwa fosil kayu Gorontalo memiliki tingkat kelayakan secara geologi yang bagus sebagai batu mulia. Tingkat kelayakan secara geologi ditinjau dari berbagai pertimbangan mulai warnanya menarik, fenomena optik tembus cahaya (translusent), terdapat corak alami serat kayu yang tidak dimiliki batu kristal umumnya, langka penyebarannya dan proses terbentuk alami.

Terpenting, fosil kayu dari daerah Gorontalo memiliki tingkat kekerasan (hardness) mencapai 7 Skala Mohs yang artinya memiliki kekerasan yang tinggi karena dari interval skala 1-10 dibanding mineral lain. Untuk skala Mohs tertinggi 10 adalah intan yang harganya sangat mahal .

Mengacu pada standar batu mulia yang dikeluarkan Gemstone Clarity Grades GIA (Gemological Institute of America Inc) (2009) maka berdasarkan karakteristik dan kualitas fosil kayu dirumuskan layak masuk pada Tipe 3 (Batu Mulia yang ditemui secara alamiah tidak bersih nampak serat kayu). Selain itu dengan hardness 7 skala Mohs maka tingkat kekerasan tinggi karena mudah menggores logam, kaca, dan batu yang lebih lembut. Bahkan, batu mulia (gemstone) dengan skala kekerasan Mohs 7 idealnya dibuat dalam bentuk liontin dan anting-anting dibanding dibuat cincin atau gelang.

Untuk itu fosil kayu Gorontalo diharapkan jangan dijual dalam bahan mentah namun diolah lebih baik dan kreatif dalam berbagai desain bentuk mulai dari batu mulia perhiasan (batu akik), plakat maupun bonsai. Namun demikian diharapkan dalam pengembangannya memperhatikan lingkungan karena lokasi penyebaran fosil kayu dikenal masih asri dan memiliki kondisi alam yang indah.

Tabel 1. Deskripsi Fosil Kayu Secara Mineralogi

\begin{tabular}{cc}
\hline Paramater & Hasil Analisa \\
\hline Warna & $\begin{array}{c}\text { Putih hingga Coklat Muda } \\
\text { (Warna Kayu) }\end{array}$ \\
\hline Cerat & Putih \\
\hline Sifat Mineral Terhadap Sinar & $\begin{array}{c}\text { Translucent, Kilap Non } \\
\text { Logam }\end{array}$ \\
\hline Kekerasan (Hardness) & 7 Skala Mohs \\
\hline Belahan & Tidak ada (hanya serat kayu) \\
\hline Sifat Kemagnetan & $\begin{array}{c}\text { Diagmagnetik (tidak menarik } \\
\text { logam) }\end{array}$ \\
\hline Daya Hantar Listrik & Tidak menghantar listrik \\
\hline
\end{tabular}

\section{Kesimpulan}

Berdasarkan hasil dan pembahasan, peneliti dapat menarik beberapa kesimpulan penting, antara lain:

1. Lokasi penyebaran fosil kayu terdapat pada satuan geomorofologi dataran alluvial dan satuan dataran fluvial di sepanjang sungai utama.

2. Penyebaran fosil kayu di daerah penelitian secara genesa ada yang insitu dan transported. Dengan posisi litologi dan stratigrafi menunjukan fosil kayu berada pada satuan batupasir tufaan.

3. Hasil analisa mineralogi maupun XRD dan XRF menunjukan bahwa kualitas fosil kayu bagus berdasarkan pertimbangan warnanya menarik, fenomena optik tembus cahaya (translusent), 
terdapat corak alami serat kayu yang tidak dimiliki batu kristal umumnya, langka penyebarannya dan proses terbentuk alami. Dengan mineral penyusun utama Quartz (Kuarsa) senyawa $\mathrm{SiO}_{2}$ dengan persentase 90-100\% yang memiliki hardness 7 skala Mohs.

4. Mengacu pada standar batu mulia yang dikeluarkan Gemstone Clarity Grades GIA (Gemological Institute of America Inc) (2009) maka berdasarkan karakteristik dan kualitas fosil kayu dirumuskan layak masuk pada Tipe 3 (Batu Mulia yang ditemui secara alamiah tidak bersih nampak serat kayu). Selain itu dengan hardness 7 skala Mohs maka tingkat kekerasan tinggi karena mudah menggores logam, kaca, dan batu yang lebih lembut. Bahkan, batu mulia (gemstone) dengan skala kekerasan Mohs 7 idealnya dibuat dalam bentuk liontin dan anting-anting dibanding dibuat cincin atau gelang.

\section{Daftar Pustaka}

[1] Andianto, N. E. L., A. Ismanto, 2012. Identifikasi Fosil Kayu dari Kali Cemoro Kabupaten Sragen, Jawa Tengah. Prosiding Seminar Nasional Biologi, Prospektif Biologi dalam Pengelolaan Sumber Hayati. Fakultas Biologi, UGM, Yogyakarta.

[2] Bachri, S., Sukido, dan N. Ratman, 1994. Peta Geologi Lembar Tilamuta, Sulawesi. Pusat Penelitian dan Pengembangan Geologi, Bandung.
[3] Badudu, J. S. dan S. M. Zein, 2001. Kamus Umum Bahasa Indonesia. Pustaka Sinar Harapan, Jakarta.

[4] Dewi, L. M. Y. I. Mandang, S. Rulliaty, Suprihatna, 2013. A New Record of Shoreoxylon (Dipterocarpaceae) Fossil Wood From Flores Island, Indonesia. Proseding 8th Pacific Regional Wood Anatomy Conference, Nanjing.

[5] Dewi, L. M, 2013. Penelitian Fosil Kayu: Status dan Prospeknya di Indonesia, Disajikan pada Diskusi Litbang Anatomi Kayu Indonesia di IPB International Convention Center, 3 Juni 2013.

[6] Gemstone Clarity Grades GIA (Gemological Institute of America Inc), 2009 http://www.rocksinmyheadtoo.com/index.html [15 Maret 2017].

[7] Hamilton, W., 1979. Tectonics of the Indonesian region. Geological Survey Proffesional Paper 1078, U.S. Govern.Printing Office, Washington. U.S.G.S. Professional Paper. 1078: 345.

[8] Katili, J. A., 1970. Past and present geotectonic position of Sulawesi, Indonesia. Tectonophysics. 45, pp. 289-322.

[9] Kavelieris, I. T. M. Van Leeuwen, M. Wilson, 1992 Geological Setting and styles of mineralisation, north arm of Sulawesi, J. SE. Asian Earth Sci. 7(2), pp. 113-129.

[10] Molnar P. and K. E. Dayem, 2010. Major Intracontinental strike-slip faults and contrasts in Lithospheric Strength, Geosphere Journal. 6(4), pp. 444-467.

[11] Palmer, D. Buku saku Fosil. Penerjemah: Yulin Lestari. Jakarta: Erlangga. http://id.wikipedia.org/wiki/Fosil. [13 Maret 2017].

[12] Satyana, A., 2007. Escape Tectonic Indonesia. http://geoblogi.wordpress.com [22 November 2016].

[13] Sompotan, A. F., 2012. Struktur Geologi Sulawesi. Perpustakaan Sains Kebumian, Bandung.

[14] Trail, D. S., T. U. John, M. C. Bird, R. C. Obial, D. A. Pertzel, D. D. Abiog, Parwata and Subagio., 1974. The General Geological Survei of Block 2 Sulawesi Utara Indonesia., PT Tropic Endeavor Indonesia. 